\title{
Barriers to E-Commerce Adoption in Syria: An Empirical Detection
}

\author{
Jaynal Uddin Ahmed \\ Professor, Department of Management, North Eastern Hill University, Tura Campus \\ Chandmari, Tura-794002, Meghalaya, India
}

Hassan Hasan

Lecturer, Department of Management and Marketing, Dhofar University

P. O. Box. No. 2509, Postal Code-211, Salalah, Sultanate of Oman

Received: April 8, 2015

doi:10.5296/wjbm.v2i1.7404
Accepted: July 3, 2015

Published: June 5, 2016

URL: http://dx.doi.org/10.5296/wjbm.v2i1.7404

\begin{abstract}
The number of Internet users in the world has been mounted over the years. By the end of 2011, more than one-third of the population was online, i.e., 2.3 billion people, and this growth has provided the impetus and the opportunities for global and regional e-commerce. However, all countries are not likely to benefit equally from the virtuous circle of Internet diffusion created by globalization and multiple revolutions in information and communication technologies. The e-commerce can reduce the economic disparity between the developing and developed countries. Despite the promises made by various international organizations, the developing countries are encountering difficulties in realizing the benefits of e- commerce. It is argued that many factors are still confound and challenging the adoption of e-commerce. In order to derive the benefits of e-commerce, region specific /country specific diagnosis of the associated factors and barriers leading to the problem is an immense necessity. Keeping in view the various initiatives undertaken by the Syrian government viz., E-Signature Legislation Project, Intellectual Property Protection Project and the National Programme for Promoting Information Technology Initiatives etc.; and considering the multifaceted issues relating to e-commerce in Syria viz., formation of contracts, cyber contracts, validity of e-transactions, dichotomy of offer and invitation to treat, mutual mistake, identity of parties etc, a study on e-commerce adoption in Syria is fascinating academic focus. Hence, the paper is an attempt to detect the main barriers to e- commerce in Syria.
\end{abstract}

Keywords: E-commerce, Barriers, Syria 


\section{Introduction}

The emergence of the Internet is a major worldwide distribution channel for goods and services, and for managerial and professionals jobs. This has tremendously changed economics, markets and industry structure, products and services and their flow; consumer segmentation, consumer values and consumer behaviour; jobs and labour markets. The e-commerce brought about changes especially for digital products. Internet based e-commerce began during mid nineties when companies recognized the advantages of the Internet as an alternative to Electronic Data Interchange systems (EDI). E-commerce is the use of Internet and web to transact business. More formally, the focus will be on digitally enabled commercial transactions between and among organizations and individuals (Laudon $\&$ Traver, 2005). However, comprehensive definitions relating to e-commerce found in Adam et al. (1998) which encompass a wide range of interactive business processes that occur before and after actual sales transactions. E-commerce activities include establishing and maintaining online relationship between an organization and its suppliers, dealers, customers, strategic partners, regulators, and other agents related to traditional delivery channels (Warkentntin, 2001). In other words, e-commerce is anything that involves an online transaction. This may range from ordering online, through online delivery of paid content, to financial dealings such as movement of money between bank accounts (Hariharaputhiran, 2012).

However, e-commerce involves much more than electronically resolved financial transactions between organizations and customers. Many commentators referred e-commerce as both financial and informational electronically mediated transactions between an organization and any third party it deals with (Chaffey, 2002). By this definition, non-financial transactions such as customer enquiries are also considered to be part of e-commerce (Marketing Online, 2006). Hence, e-commerce encompasses all business conducted by means of computer networks. The advances in telecommunications and computer technologies in recent years have made computer networks integral part of the economic infrastructure (Hariharaputhiran, 2012). As a matter of fact, a new lexicon has developed for the different e-commerce business models. It is important to recognize that the major types of e-commerce market categories are: B2C (Business to Consumer), B2B (Business to Business), C2C (Consumers to Consumers), P2P (Peer to Peer) and M-Commerce (Mobile Commerce). Amazon.com, esteel.com, eBay.com, Gnutella software and wireless mobile devices are examples on the different major types of e-commerce. The different types of e-commerce are distinguished by the nature of the market relationship except $\mathrm{P} 2 \mathrm{P}$ and M-commerce which are technology based peculiarities (Laudon \& Traver, 2005).

The number of Internet users around the world has been steadily growing. By the end of 2011, more than one-third of the population worldwide was online, i.e. 2.3 billion people (ITU, 2012), and this growth has provided the impetus and the opportunities for global and regional e-commerce (Efendioglu et al., 2004). However, all countries are not likely to benefit equally from the virtuous circle of Internet diffusion created by globalization and multiple revolutions in information and communication technologies (ICTs). Not only e- commerce has failed to bridge the economic disparity between the developing and developed countries, but it has 
actually widened it. Despite the promises made by various international organizations, the developing countries are encountering difficulties in realizing the benefits of e-commerce (Peng \& Kurnia, 2008). Hence, e-commerce is still in its infancy stage in many developing countries around the world. Many economists argue that this is due to many factors that are still confound and challenging the adoption of e-commerce (UNCTAD, 2001). Given the business potential of e-commerce in the developing countries and their difficulties in effective e-commerce adoption, it has become one of the focus areas of research agencies and academicians.

\section{Review of Literature}

A number of studies have been carried out to examine e-commerce adoption and diffusion from various perspectives (Peng \& Kurnia, 2008) and in different environment (Efendioglu et al., 2004). However, most research in e-commerce is set in the context of developed countries, though there is an increasing amount of e-commerce research specifically focused on developing countries (Mbarika et al., 2005). In fact, the majority of the studies related to e-commerce are carried out with western democratic mindset which assumes a free, stable, an efficient market environment and uniform cultural heritage within a single country (Peng \& Kurnia, 2008). Hariharaputhiran (2012) argued that advances in telecommunications and computer networks are an integral part of the economic infrastructure. The study noted that global forces which are influencing the distribution of e-commerce and its forms in developing countries include economic factors, social cultural factors, political legal factors and supranational institutions. However, Gibbs et al. (2003) noted that B2B e-commerce seems to be driven by global forces whereas B2C seems to be more of a local phenomenon. On the other hand, Kshetri (2007) analyzed e-commerce barriers/inhibitors in developing countries in terms of three categories of negative feedback systems: economic, socio-political and cognitive. While economic and socio-political factors focus primarily on the environmental characteristics, the cognitive component reflects organizational and individual behaviours. Arguably, for the initial adoption of e-commerce in developing countries, the cognitive component plays a more prominent role. As organizations assimilate sophisticated e-commerce practices, environmental factors play more critical roles. In fact, barriers prevent or limit growth, whereas inhibitors slow growth (Gibbs et al., 2003).

Political and legal issues which influence the diffusion of e-commerce in developing countries include government policies and support, legal environment and practices (Efendioglu et al., 2004). The political and legal climate of a country can significantly hinder the growth of e-commerce where there is no substantial cooperation from the government (Aljifri et al., 2003). The government policies and regulations influence the generation and use of e-commerce technology by organizations. For instance, Asian countries such as Hong Kong, India, Malaysia, Singapore, Taiwan and Thailand are providing tax and other incentives for MNCs and are promoting high-tech districts (Omestad, 2000). Higher availability of technical manpower required for B2B e-commerce is largely determined by governments' policies to develop human capital. For example, Taiwan's emphasis on technology-oriented curricula and incentives to scholars and researchers (UNDP, 2000), which has made it a global leader in B2B e-commerce. Government regulation and 
macroeconomic policies may influence firms' micro-economic policies and investments in technology and R\&D. With its microeconomic linkages, the Taiwanese government has been able to steer firms' microeconomic policies related to technology adoption (Wade, 1990). Organization-level politics also plays a role in the diffusion of B2B e-commerce. For instance, labour union protests in 1999 stopped Hyundai Motors in South Korea from implementing its marketing plan to form a strategic alliance with an Internet company (Business Korea, 2000). Other political and legal issues are also hindering the diffusion and adoption of e-commerce in many developing countries including the Arab world. Forming a company in the Arab region is difficult and labour intensive due to the complexities of navigating local partners, free zones, employee visas, and license types. The cost of a business license can run into the tens of thousands with expensive annual fees, sometimes forcing businesses to register offshore. Furthermore, in many regional countries, the laws around consumer protectionism, transaction disputes and fraud protection for online transactions are not well defined or supported (Yusuf, 2012). On the other hand, customer aversion to online payments, logistics and curbs on regional trade, including complex and different customs, tax and border regimes are obstacles to MENA e-commerce companies trying to compete on price with traditional retailers (The Middle East Magazine, 2011). In countries such as Yemen and Iraq, there are still restrictions on hard currency transfers and consumers will find it difficult to complete transactions and make payments online (Nathan, 2009).

Economic and financial factors determine whether there are sufficient resources (venture capital) to invest in e-commerce and mechanisms (payment systems, secure systems) to facilitate it (Gibbs et al., 2003). Economic factors mainly influence perceived relative advantages of Internet use and e-commerce (Kshetri, 2001; Hariharaputhiran, 2012). Economics always play an important role in encouraging the use of technology in developing countries (Economic Commission for Africa, 1999). However, economic condition in developing countries is widely recognized as a major hindrance for e-commerce adoption (Lawrence \& Tar, 2010). To measure the impact of ICT diffusion in developing countries including Latin America region, Bakay et al. (2010) analysed the ICT readiness levels on socio-economic indicators that might affect ICT either positively or negatively. The economic variables include GDP per capita, ICT expenditure percentage of GDP, Gini Index (income inequality), Unemployment rate, annual GDP growth and Human Development Index (HDI). On the other hand, factors such as investments in telecom as per cent of GDP, ICT expenditure as per cent of GDP, trade as per cent of GDP, total expenditure for R \& D as per cent of GNI, high-tech exports (per cent of Manufactured Exports), FDI as per cent of GDP are considered as important measurements for assessing the national e-readiness of a country (Bui et al., 2003).

For various geographical, political, economical and cultural reasons, developing countries are usually unable to improve their national infrastructures to the level that is common in the developed nations in the short term (Peng \& Kurnia, 2008). Travica (2002), however, developed a framework based on six layers to support the infrastructure of e-commerce in a developing country. These six layers are: telecommunications, e-payment, delivery, transportation, software industry and customer e-commerce propensity. The need to 
overcome infrastructural bottlenecks in telecommunications, transport and logistics must be addressed in parallel with the governance aspects of e-commerce, including consumer protection, security of transactions, privacy of records and intellectual property (Goldstein \& O’Connor, 2000). Efendioglu et al. (2004) identified specific infrastructure impediments that will hinder the adoption and diffusion of e-commerce in developing countries. Some of the barriers include lack of credit cards (the wide availability of them for the general public in developing countries and convenient payment means), poor distribution logistics, lack of specialized, trust-worthy online merchants of reasonable size (too many small players facing many bottlenecks and without necessary resources to set up e-commerce systems), imperfect legal system and lack of large scale telecommunication transmission capability (broadband). As users of e-commerce, the primary obstacles in the order of importance were "Internet security", "Lack of feel-and-touch associated with online purchases", "Problems in returning products" and "Selection" (product availability and breadth). In short, the lack of supporting ICT, telecommunication, logistics and banking will be a major obstacle to e-commerce adoption in the developing countries for years to come. However, the state's ability to make adequate investment to improve these infrastructures is again a major determinant of EC's future development in the developing countries. Only with an e-commerce ready national infrastructure, the organizations are able to adopt and use e-commerce to its full potential (Peng \& Kurnia, 2008). In developing countries, shopping is seen as a social place where friendly conversations between the vendor and the customer. The success of doing business depends heavily on the quality and sometimes the quantity of personal relationships. A strong individual relationship and long term association between the parties provide a sense of community and enhances social bonding. Most of the business is conducted through small enterprises and it is local. A typical company in developing country is a socio-economic entity and not just a pure economic one (Lawrence \& Tar, 2010). Thus, some business traditions that make e-commerce work elsewhere -such as catalogue shopping - do not exist in the region. For many, the ideal shopping experience is haggling over the price at a total open-air market (Rosenberg, 2002).

To sum up, electronic commerce is well-accepted in the developed world and is playing a positive role in economic development. The less-developed and developing nations are far behind in this regard, despite of the fact that the governments have had attempted to encourage e-commerce (Mohanna et al., 2011). In most developing countries there are several barriers in expanding e-commerce including basic resources, lack of infrastructure, environmental factors, education and cultural problems (Molla \& Licker, 2005; Travica, 2002; Kamalabadi et al., 2008; Gibbs et al., 2003). From the studies reviewed above reveal that most of the studies based on the problems and specific issues of e-commerce in and around. However, region specific/country specific studies relating to the barriers to e-commerce barely found. Hence, a study in respect of barriers to e-commerce in Syria is highly warranted to fill the research gap.

\section{Research Problem}

There are a very few analytical e-commerce studies in the developing world. Moreover, empirical research in the developing world lags behind in theoretical development. In order to 
derive the maximum benefit of e-commerce, region specific and/or country specific diagnosis of the associated factors and barriers leading to the problem is an immense necessity. There have been calls for research on developing country based enterprises e-commerce strategy (Kshetri, 2007). This only apart some of the multifaceted issues relating to e-commerce i.e., formation of contracts, cyber contracts, validity of e-transactions, dichotomy of offer and invitation to treat, mutual mistake, identity of parties etc. need to be understood essentially to have a better prospects of e-commerce. In the light of the above, various initiatives have been introduced by the Syrian government to activate and promote the e-commerce services and its applications in Syria, particularly, after putting the new national infrastructure of Public Data Network project (PDN) in service in the year 2005 (Syrian Telecom, 2006). It was reported that growth in the number of Internet users in Syria has been fairly steady since 2005, reaching 4,469,000 in 2011 which it represented a rate of $19.8 \%$ of the Syrian population (Wikipedia, 2013). In addition, the Syrian government has introduced many initiatives and projects such as: E-Signature Legislation Project, Intellectual Property Protection Project and the National Programme for promoting information technology initiative (UNDP-Syria, 2005). On the other hand, The Syrian Ministry of Communications and Technology has declared that there are many new services and plans with regard to the e-government project including e-commerce applications that has been introduced by the Syrian government to the public during 2012 (MOCT, 2011). Although, there have been initiatives, projects and plans related to the ICT sector introduced in Syria, there is an inadequacy in conducting out financial transactions through the Internet by both consumers and companies (UNDP-Syria, 2005). Hence, the critical question remains: why the volume of transactions based electronic commerce in Syria is limited? what impediments experienced by Syrian people for using e-commerce? Given this aforesaid scenario, the proposed study entitled, 'Barriers to E-Commerce Adoption in Syria: An Empirical Detection' has been undertaken.

\section{Objectives of the Study}

Based on the research problem identified, researchers have ventured with the objective of the study is to detect the key barriers to the development of e-commerce in Syria.

\section{Research Methodology}

\subsection{Target Population}

The Internet users in Syria have been considered as the research population of the study. The online population in Syria counted as 5.07 million which figured around 22.5 per cent of the total population as on June 2012 (IWS, 2013). For collecting the data, the field work has been carried out into major geographical provinces in Syria such as Damascus, the capital city, Der-AlZoor, Swedaa and Lattakia during the year 2013. In fact, there was absence of adequate and reliable sample frame for this research topic because the practicing of market research is still new in Syria (UNDP-Syria, 2005) and because there is a great difficulty in accessing Syrian Internet users lists at both Syrian public and private organizations for national security reasons. However, to overcome the intricacy of sample frames of Syrian Internet users, we have collected data from the locations that are related to the research topic. These locations included Internet cafes, Universities and Colleges, Private Business Houses, 


\section{MIN Macrothink}

World Journal of Business and Management

ISSN 2377-4622

2016, Vol. 2, No. 1

Government Organizations and Households. Further to that multistage method was followed to meet the objectives of the study.

\subsection{Sampling Frame}

The elements of the sample of this research were the Internet users in Syria who are 15 years and above. The sample size of the study was 550 numbers of people who have been interviewed face-to-face. The figure of 550 seems to be small compared to the target population stated earlier, but it is presumed that the high impact of face-to-face interviews survey on consumers and its high ability of targeting respondents and administrating the questionnaire will get in return high percentage of responses from Syrian Internet users. Here, it may be reiterated that it is not necessary to sample the entire population or even a substantial portion to achieve reliable results; samples of less than one percent of a population can often provide good reliability with a credible sampling procedure (Kotler, 2003). The primary data was collected from respondents by administering structured questionnaire. The respondents were students, business owners, employees and others. The face to face interview technique was adopted for the collection of data from these respondents. However, only 500 completed questionnaires finally were used for analysis and interpretation. The technique of selecting sample size is stated in Table 1:

Table 1. Distribution of the sample

\begin{tabular}{|c|l|c|c|c|c|c|}
\hline \multirow{2}{*}{$\begin{array}{c}\text { Sl. } \\
\text { No }\end{array}$} & \multicolumn{7}{|c|}{ Sample Size } \\
\hline 1 & Pyber Cafes & Damascus & Swedaa & Lattakia & Der-Al Zoor & Total \\
\hline 2 & Universities and Colleges & 25 & 25 & 25 & 25 & 100 \\
\hline 3 & Private Business Houses & 25 & 25 & 25 & 25 & 100 \\
\hline 4 & Government Organizations & 25 & 25 & 25 & 25 & 100 \\
\hline 5 & Households & 25 & 25 & 25 & 25 & 100 \\
\hline & Total & 125 & 125 & 125 & 125 & 100 \\
\hline
\end{tabular}

\subsection{Research Variables}

Based on the review of literature and approaches to e-commerce, 26 number of barrier related variables were identified taking into account of their measurability and presented in table- 2 . The opinions of the respondents on these variables were measured on a Likert scale depending on the importance against each variable. 
Table 2. Variables relating to barriers of e-commerce

\begin{tabular}{|c|c|}
\hline Sl. No & Variables \\
\hline 1 & Lack of Online security \\
\hline 2 & Lack of electrical supply \\
\hline 3 & High Internet access fees and telephone charges \\
\hline 4 & High cost of entry (cost of acquiring a computer, mobile phone, etc.) \\
\hline 5 & Lack of available online payment methods (such as credit cards) \\
\hline 6 & Problems in returning products online \\
\hline 7 & Unreliable and long delivery times \\
\hline 8 & Online censorship \\
\hline 9 & Lack of privacy of information online \\
\hline 10 & Lack of legislations regarding e-commerce \\
\hline 11 & Constraint in purchasing power \\
\hline 12 & Lack of online customer care service \\
\hline 13 & Inadequate literacy in Internet and computer usage \\
\hline 14 & Lack of English language skills \\
\hline 15 & Lack of awareness and knowledge of e-commerce benefits \\
\hline 16 & Lack of good quality of Arabic content online \\
\hline 17 & Resistance to change \\
\hline 18 & Lack of enjoyment in shopping online \\
\hline 19 & Hard to find what you are looking for \\
\hline 20 & Poor or user unfriendly web site design \\
\hline 21 & Poor Internet connection speeds \\
\hline 22 & Unavailability of other supporting new ICT infrastructures \\
\hline 23 & Lack of qualified personnel with e-commerce expertise \\
\hline 24 & Internet network is not stable \\
\hline 25 & Internet Taxes are high \\
\hline 26 & Limitation of personal contact online \\
\hline
\end{tabular}

\subsection{Technique Used}

The factor analysis was used to identify and examine the key problems of e-commerce in Syria. Factor analysis is a multivariate statistical technique that is used to summarize the information contained in a large number of variables into a smaller number of subsets of factors (Hair et al., 2003). In other words, factor analysis is essentially a data and variable reduction technique that attempts to partition of a given set of variables into groups of maximally correlated variables. For metric-scaled data on a large number of variables, factor 
analysis generates a smaller number of variables, called factors, which capture as much information as possible from the original data set (Parasuraman et al., 2009). There are two objects of factor analysis: Firstly, it simplifies the data by reducing a large number of variables to a set of a small number of variables. Secondly, it analyzes the interdependence of interrelationships among a total set of variables (Beri, 2000). With factor analysis, there is no distinction between dependent and independent variables rather all variables under investigation are analyzed together to identify underlying factors (Hair et al., 2003). One feature of factor analysis that is crucial in interpreting its result is that the factors themselves are independent. In other words, the technique constructs factors in such a way that the correlation between any pair of extracted factors will be zero, and there is no overlap or redundancy of information among the factors (Parasuraman et al., 2009). Hence, factor analysis has been carried out specifically to identify the key barriars of e-commerce in Syria.

\section{Results and Discussions}

The information system (IS) literature does not provide adequate theoretical (or empirically supported) perspectives that can be drawn on to propose a categorization of the barriers subject to investigation. Consequently, a-priori approach to develop the main underlying barrier dimensions was not seen as appropriate. Instead, we drew on an exploratory factor analysis for the impediments, thereby establishing the factors a-posteriori. For the 26 number of barrier related variables as shown in table-2, the analysis retrieved 6 factors with eigen values greater than 1 . Table 3 shows eigen values of the factors.

Table 3. Total variance explained

\begin{tabular}{|c|c|c|c|c|}
\hline \multirow{2}{*}{ Component } & \multicolumn{3}{|c|}{ Initial Eigen values } & $\begin{array}{c}\text { Rotation Sums of } \\
\text { Squared Loadings }\end{array}$ \\
\cline { 2 - 5 } & Total & \% of Variance & Cumulative \% & Total \\
\hline 1 & 5.088 & 19.568 & 19.568 & 3.168 \\
\hline 2 & 3.017 & 11.603 & 31.171 & 2.696 \\
\hline 3 & 2.019 & 7.766 & 38.937 & 2.630 \\
\hline 4 & 1.602 & 6.163 & 45.100 & 2.227 \\
\hline 5 & 1.420 & 5.463 & 50.563 & 2.179 \\
\hline 6 & 1.073 & 4.126 & 54.689 & 1.319 \\
\hline
\end{tabular}

These factors accounted for a satisfactory $54.689 \%$ of the variance besides offering a relative interpretable solution; a six-class taxonomy was employed for further investigations. Table-4 shows the rotated component matrix and the underlying variables of the extracted factors. It depicts the loadings for each underlying variable of the extracted six factors. Looking for patterns of similarity between the items that load on each factor, most of the relationships appeared logical. Only one factor, namely online (shopping) experience limitations (F5), was initially difficult to interpret as it incorporated the variable "Resistance to change", which 


\section{Al Macrothink}

World Journal of Business and Management

ISSN 2377-4622

2016, Vol. 2, No. 1

intuitively would be expected to load on the factor cognitive barriers. The item, however, dropped from further analysis on account of insufficient factor loading (0.495) for a variable measured using a Likert scale.

Table 4. Rotated component matrix ${ }^{\mathrm{a}}$ for barrier variables

\begin{tabular}{|c|c|c|c|c|c|c|}
\hline \multirow{2}{*}{ Variables } & \multicolumn{6}{|c|}{ Component } \\
\hline & 1 & 2 & 3 & 4 & 5 & 6 \\
\hline Lack of Online security & .012 & .623 & .087 & .144 & .088 & -.116 \\
\hline Lack of electrical supply & .069 & .199 & .085 & .698 & -.009 & .077 \\
\hline High Internet access fees and telephone charges & .159 & .165 & .084 & .774 & .028 & -.127 \\
\hline $\begin{array}{l}\text { High cost of entry (cost of acquiring a computer, mobile } \\
\text { phone, etc.) }\end{array}$ & .076 & .052 & .083 & .793 & .099 & .119 \\
\hline $\begin{array}{l}\text { Lack of available online payment methods (such as credit } \\
\text { cards) }\end{array}$ & .008 & .115 & .041 & .087 & .049 & .838 \\
\hline Problems in returning products online & -.022 & .667 & -.042 & .071 & .105 & .137 \\
\hline Unreliable and long delivery times & .015 & .744 & -.047 & .057 & .086 & .139 \\
\hline Online censorship & .105 & .415 & .088 & .341 & -.054 & .361 \\
\hline Lack of privacy of informat & .118 & .676 & .137 & .183 & -.034 & .000 \\
\hline Lack of legislations regarding $e-c$ & .202 & .427 & .285 & -.117 & -.121 & .377 \\
\hline Constraint in purch & .090 & .178 & .300 & .376 & .005 & .301 \\
\hline Lack of online customer care service & .027 & .551 & .237 & .053 & .029 & .043 \\
\hline Inadequate literacy in Internet and computer usage & .021 & .138 & .754 & .060 & .046 & -.040 \\
\hline Lack of English language skills & -.030 & .087 & .822 & .064 & .027 & .002 \\
\hline Lack of awareness and knowledge of e-commerce benefits & .058 & .090 & .815 & .091 & .065 & .011 \\
\hline Lack of good quality of Arabic content online & .025 & .020 & .584 & .126 & .128 & .286 \\
\hline Resistance to change & .226 & .085 & .181 & -.190 & .495 & -.024 \\
\hline Lack of enjoyment in shopping online & .104 & .097 & .169 & .028 & .713 & -.031 \\
\hline Hard to find what you are looking for & .106 & .074 & -.041 & .179 & .788 & -.062 \\
\hline Poor or user unfriendly web site design & .240 & -.032 & -.063 & .084 & .645 & .099 \\
\hline Poor Internet connection speeds & .764 & .061 & .037 & .142 & .125 & -.107 \\
\hline Unavailability of other supporting new ICT infrastructures & .802 & .105 & -.063 & .086 & .129 & -.026 \\
\hline Lack of qualified personnel with e-commerce expertise & .607 & -.037 & .087 & -.021 & .262 & .176 \\
\hline Internet network is not stable & .809 & .020 & .034 & .110 & .073 & .040 \\
\hline Internet Taxes are high & .693 & .051 & -.004 & .102 & .127 & .035 \\
\hline Limitation of personal contact online & .436 & .049 & .101 & -.091 & .429 & .140 \\
\hline \multicolumn{7}{|c|}{$\begin{array}{l}\text { Extraction Method: Principal Component Analysis. } \\
\text { Rotation Method: Varimax with Kaiser Normalization. }\end{array}$} \\
\hline \multicolumn{7}{|c|}{$\begin{array}{l}\text { a. Rotation converged in } 6 \text { iterations. } \\
\text { Italicized variable=excluded from further analysis. } \\
\text { Only variables that loaded above. } 50 \text { were considered to be a defining part of a factor, and were } \\
\text { thus included in further analysis. }\end{array}$} \\
\hline
\end{tabular}




\section{Ml Macrothink}

World Journal of Business and Management

ISSN 2377-4622

2016, Vol. 2, No. 1

The extracted factors were named ICT policy and infrastructure inhibitors (F1), lack of trust (F2), cognitive barriers (F3), cost factor (F4), online (shopping) experience limitations (F5), and online payment infrastructure barriers (F6). Table-5 shows the variables which are highly correlated with each of the six factors as follows:

Table 5. Variables related to factors

\begin{tabular}{|c|c|}
\hline Factors & Variables ( Barriers) \\
\hline \multirow{5}{*}{$\begin{array}{l}\text { Factor1 } \\
\text { ICT policy and } \\
\text { infrastructure } \\
\text { inhibitors }\end{array}$} & Internet network is not stable \\
\hline & Unavailability of other supporting new ICT infrastructures \\
\hline & Poor $\quad$ Internet connection speeds \\
\hline & Internet Taxes are high \\
\hline & Lack of qualified personnel with e-commerce expertise \\
\hline \multirow{5}{*}{$\begin{array}{l}\text { Factor } 2 \\
\text { Lack of trust }\end{array}$} & Unreliable and long delivery times \\
\hline & Problems in returning products online \\
\hline & Lack of privacy of information online \\
\hline & Lack of Online security \\
\hline & Lack of online customer care service \\
\hline \multirow{4}{*}{$\begin{array}{l}\text { Factor } 3 \\
\text { Cognitive barriers }\end{array}$} & Lack of English language skills \\
\hline & Lack of awareness and knowledge of e-commerce benefits \\
\hline & Inadequate literacy in Internet and computer usage \\
\hline & Lack of good quality of Arabic content online \\
\hline \multirow{3}{*}{$\begin{array}{l}\text { Factor } 4 \\
\text { Cost factor }\end{array}$} & High cost of entry (cost of acquiring a computer, mobile phone, etc.) \\
\hline & High Internet access fees and telephone charges \\
\hline & Lack of electrical supply \\
\hline \multirow{3}{*}{$\begin{array}{l}\text { Factor } 5 \\
\text { Online (Shopping) } \\
\text { experience limitations }\end{array}$} & Hard to find what you are looking for \\
\hline & Lack of enjoyment in shopping online \\
\hline & Poor or user unfriendly web site design \\
\hline $\begin{array}{l}\text { Factor } 6 \\
\text { Payment infrastructure } \\
\text { barriers }\end{array}$ & Lack of available online payment methods (such as credit cards) \\
\hline
\end{tabular}

However, the purpose of interdependence techniques such as factor analysis and cluster analysis is not to predict a variable from a set of independent variables, but to summarize and better understand a large number of variables or objects (Hair et al., 2003). Having observed this, the analysis reveals clearly that the nature of barriers related to the development of e-commerce in Syria is firstly infrastructural and secondly cultural and social (cognitive) inhibitors. On the other hand, the findings show that five variables which loaded less than 0.50 were not correlated with any of the six factors and shown in table- 6 . 
Table 6. Non correlated variables

\begin{tabular}{|l|}
\hline Online censorship (Political and legal) \\
\hline Lack of legislations regarding e-commerce (Political and legal) \\
\hline Constraint in purchasing power (Economic) \\
\hline Limitation of personal contact online ( Social and cultural) \\
\hline Resistance to change (Social and cultural) \\
\hline
\end{tabular}

It may be argued that as the majority of respondents are classified as individual or consumer online users, they might have not given high rates to the variables online censorship, lack of legislations regarding e-commerce and constraint in purchasing power which are not directly related to the transactions of $\mathrm{B} 2 \mathrm{C}$ e-commerce. Hence, the analysis indicates that the current situation of e-commerce in Syria is still in its infancy, specifically the B2B e-commerce transactions. In fact, the B2B market will lead consumers to the Net in developing countries, unlike in the United States, where a fast -growing consumer market enticed business online (Strauss et al., 2006). Also, the weak correlations of these variables with the factors extracted indicate that political, legal and economic variables are not currently considered as major barriers for the diffusion and adoption of e-commerce in Syria. In other words, they are less important than the infrastructural, social and cultural inhibitors which are currently limiting the growth of e-commerce in Syria. However, with regard to the other two variables named limitation of personal contact online and resistance to change, our findings reveal that the majority of our respondents are classified as heavy online users and they have "Wired" lifestyle. In other words, they have positive attitudes towards new technologies and innovations. Therefore, Syrian respondents have not given high rates to these both impediments which have social and culture nature. However, in order to identify the primary inhibitors to the development of e-commerce in Syria, we have identified the barriers according to their importance and presented in Table 7.

Table 7. Key barriers to the development of e-commerce in Syria

\begin{tabular}{|c|l|c|c|}
\hline Rank & \multicolumn{1}{|c|}{ Variables } & Frequency & Percent (\%) \\
\hline 1 & Lack of online security & 402 & 80.4 \\
\hline 2 & $\begin{array}{l}\text { Lack of available online payment methods (such as credit } \\
\text { cards) }\end{array}$ & 396 & 79.2 \\
\hline 3 & Problems in returning products online & 368 & 73.6 \\
\hline 4 & Lack of awareness and knowledge of e-commerce benefits & 354 & 70.8 \\
\hline 5 & Unreliable and long delivery times & 353 & 70.2 \\
\hline 6 & Internet network is not stable & 344 & 68.8 \\
\hline 7 & Lack of qualified personnel with e-commerce expertise & 335 & 67.0 \\
\hline 8 & Poor Internet connection speeds & 334 & 66.8 \\
\hline 9 & Lack of good quality of Arabic content online & 334 & 66.8 \\
\hline
\end{tabular}




\begin{tabular}{|c|l|c|c|}
\hline 10 & Lack of privacy of information online & 304 & 60.8 \\
\hline 11 & $\begin{array}{l}\text { High cost of entry (cost of acquiring a computer, mobile } \\
\text { phone, etc.) }\end{array}$ & 290 & 58.0 \\
\hline 12 & Unavailability of other supporting new ICT infrastructures & 288 & 57.6 \\
\hline 13 & Lack of online customer care service & 277 & 55.4 \\
\hline 14 & Lack of English language skills & 269 & 53.8 \\
\hline 15 & Lack of electrical supply & 268 & 53.6 \\
\hline 16 & Inadequate literacy in Internet and computer usage & 244 & 48.8 \\
\hline 17 & Internet Taxes are high & 237 & 47.4 \\
\hline 18 & Lack of enjoyment in shopping online & 223 & 44.2 \\
\hline 19 & High Internet access fees and telephone charges & 206 & 41.2 \\
\hline 20 & Hard to find what you are looking for & 150 & 30.0 \\
\hline 21 & Poor or user unfriendly web site design & 145 & 29.0 \\
\hline
\end{tabular}

Nonetheless, in terms of the significance of the different inhibitors, our findings were in line with the results of previous related studies (Jarvenpaa \& Todd, 1996-1997; Furnell \& Karweni, 1999; Hoffman et al., 1999; Mukti, 2000; Fenech \& O’Cass, 2001; Udo, 2001) in the sense that online security was perceived as the single most important barrier. But interestingly, the lack of available online payment methods barrier was ranked second in terms of significance as a major impediment to embracing Internet commerce in Syria. In addition, the barriers of Problems in returning products online, Lack of awareness and knowledge of e-commerce benefits and Unreliable and long delivery times respectively were perceived by the respondents as important inhibitors to the development of e-commerce in Syria.

The lack of trust in online transactions is one of the main reasons for the relatively low ecommerce adoption, especially in developing and emerging economies such as those of the countries of the Gulf Cooperation Council (GCC) (Shalhoub, 2006). For developing countries, information security issues have been compounded by the lack of trusted certificate authorities and telecommunication systems that would provide the protection needed for e-commerce to grow in that country (Aljifri et al., 2003). Therefore, effective strategic approaches regarding the situation of Internet security and telecom infrastructure must be deployed in Syria for the future of e-commerce and other technologies (UNDP-Syria, 2004). It appeared that the lack of e-payment methods is one of the most key challenges to the adoption and diffusion of e-commerce in Syria. There are currently 20 licensed banks in Syria (Central Bank of Syria, 2014). By the end of first quarter of 2010, the number of private, Islamic, and state-owned banks which were functioning in Syria was 11, 3, 6 respectively (Al-Wasat Newspaper, 2010). As part of the e-government project, only two state-owned banks have recently started to introduce few of the e-payment services such as electricity and water bills. However, lack of bank accounts and hence credit cards, complicated administrative banking procedures, low Internet connection speeds, lack of reliable e-payment methods and finally lack of awareness of e-banking services are considered as the most key barriers which have hindered the adoption 
and diffusion of e-government in Syria (Darrag, 2012). Furthermore, Internet banking in the Middle East, a region where cash is still king, is in its infancy (Drummond, 2000). The Indicators of Information Society in Syria (2004) revealed that the number of cash machines in Syria is very limited and the majority of ATMs services now exist only in Damascus, the capital of Syria (UNDP-Syria, 2005). In addition, the quality of ATMs services is very poor. The majority of ATMs in Damascus are out of service or empty. Customers will run from one ATM to another. It's like a 'Marathon', and one can easily see a long queue of people waiting in front of the ATMs (Syria News, 2014).

The analysis clearly shows that the nature of the key barriers to the development of e-commerce in Syria is infrastructural, cultural and social (cognitive). Key infrastructural impediments, mainly, includes the Lack of online security, Lack of available online payment methods, Problems in returning products online, Unreliable and long delivery times, Internet network is not stable, lack of qualified personnel with e-commerce expertise and Poor Internet connection speeds. These infrastructural inhibitors can be categorized into four groups: Lack of trust, Payment infrastructure, logistics and ICT infrastructure. Key cognitive barriers, however, are Lack of awareness and knowledge of e-commerce benefits and lack of good quality of Arabic language online. However, it is also noted that none of the key barriers listed above had a political or economic nature. On the other hand, Syrian respondents rate Poor user or friendly web site design as the single least barrier, followed by Hard to find what you are looking for, High Internet access fees and telephone charges, Lack of enjoyment in shopping online, Internet Taxes are high and Inadequate literacy in Internet and computer usage. Again these findings, to a great extent, supported that the vast majority of our respondents can be classified as heavy and tech-savvy online users. The term tech-savvy refers to the proficient ability to navigate and use typical computer programs for a given task or project (Urban Dictionary, 2011).

With regard to the level of satisfactions, the findings of the research have clearly showed that the vast majority of respondents were extremely disappointed with the current situation of the Internet services and other technologies provided by the Syrian government and other Internet Service Providers (ISPs) operating in Syria. Table 8 presented the level of satisfaction of the respondents in respect of Internet services.

Table 8. Level of satisfactions with regard to ICTs in Syria

\begin{tabular}{|l|l|c|c|c|c|}
\hline \multicolumn{2}{|c|}{} & Frequency & Percent & Valid Percent & Cumulative Percent \\
\hline \multirow{4}{*}{ Valid } & Poor & 139 & 27.8 & 27.8 & 27.8 \\
\cline { 2 - 6 } & Fair & 253 & 50.6 & 50.6 & 78.4 \\
\cline { 2 - 6 } & Good & 96 & 19.2 & 19.2 & 97.6 \\
\cline { 2 - 6 } & Excellent & 12 & 2.4 & 2.4 & 100.0 \\
\cline { 2 - 6 } & Total & 500 & 100.0 & 100.0 & - \\
\hline
\end{tabular}

It is depicted from the table that $78.4 \%$ of the respondents stated that they are fairly or poorly 
satisfied with the current situation of the domain of Information and Communication Technologies (ICTs) including Internet services in Syria. Only less than $25 \%$ of the respondents revealed their positive perceptions. The importance of this finding comes from its ability to show with evidence - the inadequacy of telecom infrastructure and Internet technologies in Syria. Syria is intensely suffering from inadequate infrastructure to embark on e-commerce and other technologies. The physical communication as well as a telecommunication network would prevent the countries from being digitally competitive. Hence an urgent step is warranted with economic and administrative mechanism for ICT sector and its potential in opening new opportunities in the Syrian market.

\section{Acknowledgement}

The research is financed by Indian Council for Cultural Relations, New Delhi. Thanks for Prof. Eugene D Thomas, Pro Vice Chancellor, North Eastern Hill University, Tura Campus, Meghalaya, India.

\section{References}

Adam, N. et al. (1998). Electronic Commerce: Technical, Business, and Legal issues. NJ: Printice Hall.

Aljifri, H., Pons, A., \& Collins, D. (2003). Global E-commerce: A Framework for Understanding and Overcoming the Trust Barrier. Journal of Information Management \& Computer Security, 11(3), 130-138. http://dx.doi.org/10.1108/09685220310480417

Al-Wasat, N. (2010). Private Banks in Syria Calls to Ask Treasury Bonds to Stimulate Investment Opportunities. Retrieved August 25, 2014 from http://www.alwasatnews.com/2857/news /read/438436/1.html

Bakay, A., Okafor, C. E., \& Ujah, N. U. (2010). Factors explaining ICT Diffusion: Case Study of Selected Latin American Countries. The International Journal on Advances in ICT for Emerging Regions, 3(2), 25-33.

Beri, G. (2000). Marketing Research. Tata McGraw-Hill Publishing Company Limited, New Delhi.

Bui, T. X., Sankaran, S., \& Sebastian, I. M. (2003). A Framework for Measuring National E-readiness. International Journal of Electronic Business, 1(1), 3-22. http://dx.doi.org/10.1504/IJEB.2003.002162

Business Korea. (2000). Traditional Retailers Feel Threatened by Rise of E-commerce. Business Korea, 17(4), 24-6.

Central Bank of Syria. (2014). Directory of Banks Operating in Syrian Arab Republic. $\begin{array}{llll}\text { Retrieved } \quad \text { August } & 25, & \text { from }\end{array}$ http://www.banquecentrale.gov.sy/ban-sup/Syrian-banks/BanksDirectory.PDF

Chaffey, D. (2002). E-Business and E-Commerce Management, London: Pwarson.

Darrag, M. (2012). E-Government Takes Off from its First Stop to Pay Utility Bills: Terms of 
Conditions: Availability of Bank Accounts for Subscribers, Fast Internet Network and without faults. Retrieved August 25, 2014 from http://www.syriasteps.com/?d=126\&id=88100

Drummond, J. (2000). Technology Proceeds at Slow Pace: E-banking by James Drummond: Internet Trading and Cyber Cafes are Making their Appearances, But This is Still a Region Where Cash is King. Financial Times, London.

Economic Commission for Africa. (1999). African Information Infrastructure. Retrieved April 22, 2006 from http://www.un.org/Depts/eca/adf/infrastructure.htmst

Efendioglu, A. M., Yip, V. P., \& Murray, L. W. (2004). E-Commerce in Developing Countries: Issues and Influences. University of San Francisco Press, Retrieved August 4, 2012 from http://userwww.sfsu.edu/ ibec/papers/25.pdf

Fenech, T., \& O’ Cass, A. O. (2001). Internet Users' Adoption of Web Retailing: User and Product Dimensions. Journal of Product \& Brand Management, 10(6), 361-381. http://dx.doi.org/10.1108/EUM0000000006207

Furnell, S. M., \& Karweni, T. (1999). Security Implications of Electronic Commerce: A Survey of Consumers and Businesses. Internet Research: Electronic Networking Applications and Policy, 9(5), 372-382. http://dx.doi.org/10.1108/10662249910297778

Gibbs, J., Kraemer, K. L., \& Dedrick, J. (2003). Environment and Policy Factors Shaping Global E-Commerce Diffusion: A Cross-Country Comparison. The Information Society: An International Journal, 19(1), 5-18. http://dx.doi.org/10.1080/01972240309472

Goldstein, A., \& O' Connor, D. (2000). E-Commerce for Development: Prospects and Policy Issues, Working Paper No. 164, Organization for Economic and Co-operation Development, $\begin{array}{lllll}\text { Retrieved July } & \text { 8, } & \text { from }\end{array}$ http://www.oecdilibrary.org/docserver/download/5lgsjhvj7b25.pdf?expiress[m=6

Hair, J., Bush, R. B., \& Ortinau, D. J. (2003). Marketing Research Within a Changing Information Environment. New York: McGraw-Hill Irwin.

Hariharaputhiran, S. (2012). Challenges and Opportunities of E-Commerce. International Journal of Marketing, Financial Services \& Management Research, 1(3). Retrieved July 18, 2014 from http://indianresearchjournals.com /pdf/IJMFSMR/2012/March/10.pdf

Hasan, H., \& Ahmed, J. U. (2013). E-Commerce in Syria: Overall ICT Perspective. International Journal of Applied Management Research, 1(2), 75-99.

Hoffman, D. L., Novak, T. P., \& Peralta, M. (1999). Building Consumer Trust Online. Communications of the ACM, 42(4), 80-85. http://dx.doi.org/10.1145/299157.299175

ITU: International Telecommunication Union. (2012). Measuring the Information Society 2012. Retrieved August 26, 2013 from http://www.itu.int/en/ITU-D/Statistics/Documents/ publicat ions/mis2012/MIS2012_without_Annex_4.pdf

IWS: Internet World Stats. (2013). Middle East Internet Users, Population and Facebook Statistics. Retrieved August 29, 2013 from http://www.internetworldstats.com/stats5.htm 
Jarvenpaa, S. L., \& Todd, P. A. (1996-1997). Consumer Reactions to Electronic Shopping on the World Wide Web. International Journal of Electronic Commerce, 1(2), 59-88. http://dx.doi.org/10.1080/10864415.1996.11518283

Kamalabadi, I. N., Bayat, A., Ahmadi, P., \& Ebrahimi, A. (2008). Identifying and Prioritization of Challenges and Barriers of E-Commerce Implementation in Iran. World Applied Sciences Journal, 5(5), 590-597.

Kotler, P. (2003). Marketing Management. USA: Prentice Hall International Editions.

Kshetri, N. (2001). Determinants of the Locus of Global E-commerce. Electronic Markets, 11(4), 250-257. http://dx.doi.org/10.1080/101967801753405535

Kshetri, N. (2007). Barriers to E-commerce and Competitive Business Models in Developing Countries: A Case Study. Journal of Electronic Commerce and Applications, 6(4), 443-452. http://dx.doi.org/10.1016/j.elerap.2007.02.004

Laudon, K., \& Traver, C. (2005). E-Commerce: Business. Technology. Society. India; Sanat Printers, Pearson Education.

Lawrence, J. E., \& Tar, U. A. (2010). Barriers to E-commerce in Developing Countries. Information, Society and Justice, 3(1), 23-35.

Marketing Online. (2006). An Introduction to Internet Marketing. Retrieved August 19, 2006 from http://www.marketing-online.co.uk/ch1.pdf

Mbarika, V. W., Okoli, C., Byrd, T. A., \& Datta, P. (2005). The Neglected Continent of IS Research: A Research Agenda for Sub-Saharan Africa. Journal of the Association for Information Systems, 6(5), 130-170.

MOCT: Ministry of Communications and Technology. (2011). E-government in Syria. Retrieved August 3, 2012 from http://www.moct.gov.sy/moct/?q=ar/node/239

Mohanna, S., Yaghoubi, N., Motlaq, S., \&Motlaq, T. (2011). Limitations of E-commerce in developing countries: Study of Iran. American Journal of Scientific and Industrial Research. http://dx.doi.org/10.5251/ajsir.2011.2.2.224.228

Molla, A., \& Licker, P. S. (2005). E- commerce Adoption in Developing Countries: A Model $\begin{array}{llll}\text { and Instrument. Information \& Management, } 42, & 877-899 .\end{array}$ http://dx.doi.org/10.1016/j.im.2004.09.002

Mukti, N. (2000). Barriers to putting business on the internet in Malaysia. Electronic Journal on Information Systems in Developing Countries, 2(6), 1-6.

Nathan, R. J. (2009). Electronic Commerce Adoption in the Arab Countries-An Empirical Study. International Arab Journal of e-Techno, 1(1), 29-37. Retrieved July 23, 2014 from http://www.iajet.org/iajet_files/vol.1/no.1/EC\%20Adoption\%20in\%20Arab\%20CountriesRob ertJ_IAJeT.pdf

Omestad, T. (2000). Building a High-Tech Magnet: Is this Cybercity a Bold Move or a Boon 
Doggle? Cyber Jaya Malaysia. US News and World Report, $25^{\text {th }}$ September.

Parasuraman, A., Grewal, D., \& Krishnan, R. (2009). Marketing Research. New Delhi, Dreamtech Press.

Peng, F., \& Kurnia, S. (2008). Exploring the National Context in Electronic Commerce Adoption in Developing Countries. Pacific Asia Conference on Information Systems. $\begin{array}{llll}\text { Retrieved July } & 18, & 2014 & \text { from }\end{array}$ http://aisel.aisnet.org/cgi/viewcontent.cgi?article=1171\&context=pacis2008

Rosenberg, D. (2002). E-commerce: Selling Strategies-International: No Sale-Economic and Cultural Barriers Continue to Keep E-commerce from Clicking in the Midldle East. Wall Street Journal, New York.

Shalhoub, Z. (2006). Trust, Privacy and Security in electronic business: The case of the GCC countries. Journal of Information Management \& Computer Security, 14(3), 270-283. http://dx.doi.org/10.1108/09685220610670413

Strauss, J., El-Ansary, A., \& Frost, R. (2006). E-Marketing. Printce-Hall of India Private Limited, New Delhi.

Syria News. (2014). Real Estate: ATMs Operate in Periods of Rationing. Retrieved August 25, 2014 from http://syrianow.sy/?d=3\&id=109321

Syrian Telecom. (2006). Plans and Projects/ The Public Network for Data. Retrieved August 21, 2006 from http://www.ste.gov.sy/?act=plans

The Middle East Magazine. (2011). Foreign Investment Boosts the Regions Confidence in E-Commerce. Retrieved July $16, \quad 2014$ from http://www.themiddleeastmagazine.com/news-detail.php?nid=168

Travica, B. (2002). Diffusion of Electronic Commerce in Developing Countries: The Case of Costa Rica. Journal of Global Information Technology Management, 5(1), 4-24. http://dx.doi.org/10.1080/1097198X.2002.10856317

Udo, G. J. (2001). Privacy and Security Concerns as Major Barriers for E-commerce: A Survey Study. Information Management \& Computer Security, 9(4), 165-174. http://dx.doi.org/10.1108/EUM0000000005808

UNCTAD: United Nations Conference on Trade and Development. (2001). E-Commerce and Development Report. United Nations, Retrieved July 12, 2014 from http://unctad.org/en/Docs/ecdr2001_en.pdf

UNDP- Syria: United Nations Development Programme-Syria. (2005). Indicators of Information Society in Syria for 2004. Damascus. Syria.

UNDP- Syria: United Nations Development Program-Syria. (2004). National ICT Strategy for Socio-Economic Development in Syria. Damascus. Syria. Retrieved March 16, 2014 from http://www.arab-hdr.org/publications/other/undp/hdr/2004/syria-ict-04e-strategy.pdf 


\section{Macrothink}

World Journal of Business and Management

ISSN 2377-4622 2016, Vol. 2, No. 1

UNDP: United Nations Development Program. (2000). Human Development Report, New York. Retrieved July 11, 2001 from http://www.undp.org/hdr2001/completenew.pdf

Urban Dictionary. (2011). Tec savvy. Retrieved November 23, 2013 from http://www.urbandictionary. com/define.php?term=tech\%20savvy

Wade, R. (1990). Governing the Market: Economic Theory and the Role of Government in East Asian Industrialization. Princeton University Press.

Warkentin, M. (2001). The Next Big Thing in e-commerce. Decision Line, 32(1), 7-10.

Wikipedia. (2013). Telecommunications in Syria. Retrieved August 29, from http://en.wikipedia.org/wiki/Telecommunications_in_Syria

Yusuf, M. A. (2012). Five Must - Haves for Igniting e-Commerce in the Arab World. Retrieved July 23, 2014 from http://www.wamda.com/2012/01/five-must-haves-for-igniting-e-commerce-in-the-arab-world

\section{Copyright Disclaimer}

Copyright for this article is retained by the author(s), with first publication rights granted to the journal.

This is an open-access article distributed under the terms and conditions of the Creative Commons Attribution license (http://creativecommons.org/licenses/by/3.0/). 